\title{
MULHERES HIV-POSITIVAS E GRÁVIDAS. DIFICULDADES DENTRO DO CASAL. EXPERIÊNCIA NUMA ASSOCIAÇÃO PARISIENSE*
}

Béatrice Martin-Chabot

Psicóloga clínica

na Associação

"Dessine-moi un mouton".

Tradução: Pedro Henrique Bernardes Rondon
RESUMO: O apoio à reflexão, a fim de estimular a dinâmica de vida abalada pelas angústias despertadas pelo anúncio de um resultado positivo na sorologia para o vírus da imunodeficiência humana (HIV), para a mulher que sabe que está grávida, exige abordagem benevolente. Constatamos que ante o anúncio desse diagnóstico, mortal a um prazo mais ou menos longo, a possibilidade de transmissão pela via materno-fetal é tomada em consideração pela mulher a quem se comunica que é satisfatório o resultado do protocolo médico de redução de riscos de transmissão da mãe à criança. Em compensação, os riscos de contaminação pela via sexual com seu parceiro impõem que essa mulher pense, pelo menos uma vez, como vai fazer para falar com ele, ou se vai se calar, com medo de ser levada a mal e rejeitada. Trata-se, portanto, além do sentimento de periculosidade ligado a esse vírus, de abrir para essa mulher uma reflexão acerca daquilo que é importante: para ela própria, para seu futuro, para o futuro do casal e para o futuro de seu filho que vai nascer.

Palavras-chave: Soropositividade para o HIV, periculosidade, sofrimento ligado ao silêncio, insinuações, mentiras.

ABSTRACT: HIV-positive and pregnant women. Difficulties of a coupleExperience in an association in Paris. To support reflection in order to encourage the dynamics of life upset by the anxiety brought about by the announcement of HIV positive testing for a woman who learns that she is pregnant, requires empathy. We realize that the announcement of a fatal prognosis in a more or less distant future, the possible transmission of the virus to the fœtus is taken into account by a woman who is told about the medical protocol

\footnotetext{
* Publicado sob o título "Des femmes enceintes séropositives au virus du sida, entre secret et parole au sein du couple”, em Dialogue Érès, n.179, p.111-118, 2008/1.
} 
to reduce the risks of transmission between mother and child. However, the risk of transmission through sexual intercourse with her partner incites her to contemplate - at least once - the possibility of telling him or to remain silent for fear of being ill-considered and rejected. The point is that, in addition to the feeling that the virus is dangerous, the woman should consider what is important for herself, for her own future, for the future of the couple and of the child to be born.

Keywords: HIV positive testing, the dangerous character, suffering related to silence, insinuation, lies.

$\mathrm{N}$ a França, mais de 25 anos depois do início da epidemia do vírus da imunodeficiência humana (HIV), apesar dos progressos terapêuticos que permitem mais esperança de vida, o diagnóstico de soropositividade para o HIV continua sendo sinônimo de morte e de vergonha, uma vez que essa patologia está ligada ao sexo e ao sangue. Como veremos, é importante estar atento para oferecer apoio à mulher para refletir sobre a dinâmica de vida individual das pessoas infectadas, e sua relação com as outras pessoas.

\section{APRESENTAÇÃO DO CONTEXTO DESSA EPIDEMIA}

Foi em 1981 que médicos americanos começaram a se questionar acerca do aparecimento de doenças em pessoas cujo sistema imunológico estava fortemente alterado - homens jovens e homossexuais. Em 1982, continuou-se a constatar esse fenômeno em escala mundial, na população de ambos os sexos (sendo as mulheres a minoria). O aumento do número de hemofílicos e de pessoas que tinham recebido transfusões de sangue levou a supor que a via hematológica, além da via sexual, era um modo de contaminação. Essas infecções e esses tumores foram chamados Aids, sigla do nome inglês da Síndrome de Imunodeficiência Adquirida. Foi em 1983 que se identificou o vírus da Aids. Em 1985 foi proposto à população um exame para o diagnóstico sorológico, o que levou a um novo movimento de pânico. De fato, os testes revelam que pessoas sadias podem ser portadoras do vírus, são chamadas soropositivas, ou HIV-positivas. As pessoas doentes de Aids, portanto, são apenas a ponta do iceberg. Foram declarados grupos de risco: os homossexuais, os toxicômanos e as prostitutas; os hemofílicos e as pessoas que receberam transfusões de sangue ficaram fora disso por conta das medidas tomadas junto aos centros de hematologia (depois de muitos anos). Viuse igualmente crescer o número de mulheres contaminadas, e o aparecimento 
dos primeiros casos pediátricos, essencialmente em consequência da transmissão materno-fetal e do aleitamento, além de alguns casos de transfusão de sangue em crianças hemofílicas.

Até 1996, era preciso esperar que a criança fizesse 2 anos para se fazer o diagnóstico de soropositividade ou soronegatividade naquela que fosse filha de mãe HIV-positiva. De fato, toda criança nasce com os anticorpos de sua mãe, e leva de 18 a 24 meses para fabricar seu próprio sistema imunológico.

Em nossos dias, graças a uma nova técnica de exame, é preciso esperar que o bebê tenha 3 meses para que se tenha uma confirmação de seu diagnóstico. A Aids é sempre mortal, e em 1987 o AZT foi proposto como terapêutica, mas se revelou pouco eficaz. Só em 1992 apareceu uma segunda molécula antirretroviral. Combinada à primeira, foram obtidas algumas melhoras, mas os óbitos continuaram a se multiplicar. Uma terceira molécula foi comercializada em 1994, e só em 1996 conseguiu-se o verdadeiro sucesso na parada da progressão em direção à doença, com a descoberta das antiproteases, com as quais são propostos os coquetéis antirretrovirais ou terapias tríplices.

Desde então tem havido poucas descobertas importantes. A pesquisa tem permitido a fabricação de novas moléculas, introduzindo novas combinações terapêuticas (coquetéis antirretrovirais), mas essencialmente o que tem havido são melhorias do condicionamento dos medicamentos, o que permite a diminuição do número de tomadas, e dos efeitos colaterais. A partir de 1994 foi proposto a toda mulher HIV-positiva grávida um protocolo de redução dos riscos de transmissão do vírus da mãe ao filho. As taxas de contaminação passaram, então, de cerca de $25 \%$ para cerca de $8 \%$, para cair a $1 \%$ o risco de que uma criança nasça soropositiva.

Winnicott observava que um bebê não existe sozinho nunca; a mesma coisa eu observo quando encontro uma mulher grávida: considero a presença ou a ausência de um homem, pai dessa criança que vai nascer.

No que se refere ao encargo de orientar as mulheres grávidas HIV-positivas, na associação parisiense em que trabalho elas são encaminhadas sobretudo pelas maternidades, após o diagnóstico de soropositividade ante o anúncio de sua gravidez, ou no decurso do acompanhamento pré-natal, por intermédio de associações de luta contra a Aids, ou mais raramente pela divulgação boca a boca.

Nosso papel é ajudá-las a refletir sobre a vida que levam dentro delas, apesar do abalo e da angústia que o anúncio do HIV suscita no momento em que descobrem estar grávidas.

Somos levados a encontrar dois tipos de situações: uma em que a mulher descobre sua soropositividade ao vírus HIV no curso de uma gravidez; outra 
em que ela engravida já sabendo que é HIV-positiva. A concepção dessa criança, sinônimo de vida, é então reveladora, ou mesmo uma chamada à ordem (em função do protocolo de redução de riscos de transmissão da mãe ao filho com o início do tratamento), de que o vírus HIV, sinônimo de morte, está circulando nesse mesmo corpo. Em todo caso, tenha ou não a mulher tido conhecimento de seu estatuto sorológico, a criança concebida pode ser “desejada”, ou uma "surpresa”, ou um “acidente”. A proposta de aborto (IVG) é sempre, para essas mulheres, uma reflexão dolorosa em que se misturam a moral, as crenças, o medo de contaminar o filho, o medo de sua própria morte, e também o anseio de 'dar vida'. A decisão de dar continuidade à gravidez, ou de manter a gravidez, como algumas dizem, fica sempre marcada por forte ambivalência mais ou menos bem vivida, e algumas vezes mesmo por uma cisão, que vão repercutir nas relações mãe/filho.

Essas mulheres estão debaixo do choque do anúncio de um diagnóstico mortal, a um prazo mais ou menos longo, sem distinguir exatamente a diferença entre soropositividade ao vírus HIV e Aids, ou estão debaixo do choque da confirmação desse diagnóstico. Diagnóstico que se confirma no caso de determinadas mulheres que já tinham pensado que podiam ter sido contaminadas, mas nunca tinham procurado se certificar disso por meio de um exame. Aqui, o teste é proposto dentro do quadro da gravidez. Para outras mulheres que tinham conhecimento de sua sorologia, essa gravidez vem, de alguma maneira, atualizar a verdade do diagnóstico que, com frequência, tentam esquecer ou desmentir.

Somos, portanto, levados a receber mulheres que, com sua gravidez, ficam sabendo (ou confirmam) que são HIV-positivas, doença sexualmente transmissível e há, então, razão de nos preocuparmos também com o cônjuge, além dos riscos de contaminação da criança. Constatamos que a futura mãe, em certa medida, tem capacidade de compreender mais rapidamente os riscos de contaminação da criança que leva dentro de si do que os riscos implicados nas práticas sexuais com seu companheiro, uma vez que compreende que vai seguir um protocolo para reduzir os riscos em relação a seu bebê. No momento em que ela toma conhecimento de sua soropositividade, momento traumatizante, como pensar nos outros? Mesmo em seu próprio parceiro, pelo qual ela pode pensar que foi contaminada sem, no entanto, ter tanta certeza disso, e pelo qual teme ser levada a mal, e talvez até abandonada.

Como psicóloga, a necessidade de acompanhar a reflexão da pessoa contaminada, em seguida a outros profissionais, de ter que fazê-la falar sobre isso com seu parceiro sexual, deve ser conduzida com a máxima "empatia”, uma vez que isso pode ter como consequência reforçar os sentimentos de culpabilidade, talvez mesmo de vergonha, paralisando qualquer possibilidade de falar. O anúncio da soropositividade ao HIV provoca tal abalo psíquico, algumas vezes com um 
tempo de perplexidade, que refletir sobre as consequências possíveis para o outro é algo que quase sempre fica fora de alcance da pessoa envolvida.

Nossa experiência nos faz constatar que a escuta numa neutralidade "pulsional” e com benevolência "narcísica”, logo em seguida ao anúncio da soropositividade, dá ao sujeito um espaço em que pode evocar suas experiências ante a soropositividade, ante sua soropositividade, ante a Aids, e ajuda a perceber que os sentimentos de vergonha e culpa podem ser acolhidos por aquele que escuta, e não vão ser desconsiderados. Trata-se, de fato, de dar um espaço para pensar, permitindo preservar a continuidade do sentimento de existir da pessoa, que pode falar com um outro capaz de receber de maneira "benevolente" as experiências de anulação e as angústias sentidas. E é somente num segundo tempo que a mulher vai poder pensar nas consequências para seu cônjuge. Essa reflexão sobre as consequências deve ser levada com seu cônjuge, e não para ele nem contra ele - cônjuge, isto é, parceiro sexual com quem é necessário, talvez mesmo indispensável, falar dessa "novidade", para poder sentir-se existir, sentir-se inteira. Novidade tanto mais difícil do que o seria o anúncio, por exemplo, de um câncer para o qual vai ser preciso submeter-se a pesado tratamento para tentar curar-se, e para o qual é necessário ser apoiado: é o anúncio de um estado de periculosidade. Periculosidade para si mesma, uma vez que não há tratamento para curar, e periculosidade para o outro, uma vez que há riscos de transmitir o vírus.

Esse sentimento de periculosidade pode ser reforçado se, em nossa intervenção, assumirmos atitude moralizante, com uma frase do tipo "É importante para a saúde dele que você lhe conte”. Não obstante a atitude seja justificada pela preocupação com o outro, mas nesse exato momento, não tem a ver com o cuidado da paciente que estamos atendendo. Para nós, como psicólogos, trata-se de abrir a reflexão acerca de como é importante, para essa mulher grávida HIV-positiva, ouvir aquilo que é importante para ela e a maneira como poderá viver isso, falar ou não falar daquilo que a toca, importante para seu futuro, para o futuro de seu casamento, e para o futuro de seu filho que vai nascer. Na nossa escuta os temas que geralmente são trabalhados, de acordo, é claro, com o progresso no encaminhamento da reflexão pessoal de cada mulher, se referem mais ao peso de um sofrimento que ela precisa conter sozinha, sem poder compartilhá-lo com mais ninguém - companheiro, pais, irmão ou irmã, amigos, etc. — uma parte de sua história que emocionalmente ocupa tanto espaço na vida psíquica da pessoa. Compartilhar algo que se experiencia tem o sentido de confirmar, graças ao outro, aquilo que o sujeito vive (necessidade de reconhecimento tanto no território do prazer quanto do desprazer). É uma necessidade mais ou menos grande de o sujeito confirmar, restaurar, ou apoiar seu sentimento de existir na continuidade. O peso do silêncio de certo modo leva a o sujeito a não se sentir 
inteiro, a não se sentir verdadeiro, a estar sempre num funcionamento que, seguindo Winnicott, poderíamos chamar de falso self, ou ainda leva a um sentimento de estar encerrado, isolado, com sua contrapartida - o sentimento de ser rejeitado. Esse funcionamento em forma de falso self, e esse sentimento de ser excluído, será proporcional à força com a qual o sujeito desejaria desmentir essa parte de si que lhe é insuportável, tornada vergonhosa desde o diagnóstico de soropositividade ao vírus da Aids. E é porque não se sustenta, e não funciona, que esse desmentido provoca sofrimento suscetível de conduzir o sujeito a refletir. O peso da mentira é uma variante do peso do silêncio, pesa sobre o cotidiano e sobre a dificuldade de então poder dizer a "verdade", postergando incansavelmente o momento de falar, porque "nunca é o momento certo", com a ilusão de que mais tarde vai ficar mais fácil.

Mas eu gostaria especialmente de falar aqui do peso daquilo que podemos chamar de meias-mentiras, e das consequências que acarretam. De fato, constatamos há muitos anos que, para as mulheres soropositivas grávidas que já conheciam seu diagnóstico, na maioria das vezes depois de sua gravidez anterior, mas que nunca falaram sobre isso com seus maridos, ou com o futuro pai da criança que vai nascer, acontece que o pessoal das maternidades, desejando proteger o parceiro, se aproveita da situação dessa nova gravidez para iniciar e/ ou sustentar o anúncio da soropositividade da mulher ao companheiro, dizendo que ela acabou de ficar sabendo de sua sorologia ao HIV por ocasião dos exames da atual gravidez. Na ocasião, as mulheres em questão e a equipe experienciam alívio: "enfim, está dito".

Um ou dois anos depois, no contexto do acompanhamento ambulatorial que o enquadre de nossa associação oferece, ouvimos essas mulheres evocarem brigas de casal e muitas vezes separações violentas sem possibilidade de reconciliação. Conforme o que dizem, o Cavalheiro se recusa a falar, e se o casal discute, isso termina em violência que muitas vezes é física. Na maioria das situações, quando pergunto desde quando, na opinião delas, surgiram as dificuldades do casal, após uma primeira resposta de tipo circunstancial (uma mudança de residência, um novo emprego, uma vaga em creche, etc.), elas seguem a associação de ideia evocando que faz muito tempo que eles não conversam, com o sentimento de que vivem um ao lado do outro, mas não juntos. Remontam então à ocasião do anúncio da soropositividade, por ocasião de uma consulta na maternidade, ou numa consulta pediátrica. Essas mulheres relatam que o médico disse ao companheiro que elas eram soropositivas, e que desde então o casal nunca conversou sobre isso. Especialmente se a sorologia do Cavalheiro se revelou negativa.

Vou propor aqui uma rápida ilustração clínica que reagrupa o conjunto dos parâmetros dessas situações: a Sra. J. é encaminhada por uma associação de luta contra a Aids, porque ela é mãe de duas crianças (uma de 4 anos, a outra 
de 11 meses), e está em pânico ante a ideia de que no futuro vai ter que cuidar sozinha de seus filhos, uma vez que seu companheiro (eles não são casados) vai deixá-la no fim do mês. A explicação dada é que a Sra. J. trabalha longe de sua residência, e que era o Cavalheiro quem garantia os horários de creche e de escola das crianças até agora. A Sra. J. telefona e marca uma entrevista. Relata sua história a partir da gravidez de sua filha mais velha, ocasião em que ficou sabendo que era soropositiva. Ela ficou tão perturbada que se recusou a falar sobre isso com seu companheiro, com medo de que ele a abandonasse, agora, que ela estava grávida e queria ter a criança. Sem dar outros pormenores, lembra que eles ficaram separados durante um período em que o Cavalheiro foi levado a trabalhar numa cidade menor, pois a nova gravidez tinha chegado. Na maternidade a equipe a estimulou a falar ao pai das crianças, e propôs-se a recebê-lo junto com ela por ocasião da próxima consulta, para dizer a ele que, no decurso dos exames da gravidez, a Sra. J. acabara de ficar sabendo que estava contaminada pelo HIV. Dito e feito.

A Sra. J. conta que foi proposto ao companheiro que fizesse ele próprio um exame, o qual se revelou negativo. Nesse momento da entrevista, a Sra. J. voltou às suas inquietações do momento: como vai fazer para gerir sozinha a sua vida diária? No nível do casal, ela diz que é impossível discutir com o pai de seus filhos, há crises de violência. Faz um mês que o Cavalheiro lhe disse que ia embora no final desse mês; eles vivem passando um pelo outro e mal se olham. Quando ela chega do trabalho, ele sai. Eles não discutiram nada quanto ao futuro a propósito da organização da família. A Sra. J. se lembra de que não consegue mais conversar com ele, porque não o vê mais (a ideia de se valer de um intermediário não lhe parece uma solução).

Quando lhe pergunto a partir de quando as coisas ficaram degradadas no casal, uma vez que o menino mais novo tem 11 meses, ela responde que foi desde que eles se mudaram (há oito meses). Segue falando de sua última gravidez, do nascimento prematuro da criança, seu temor pela saúde do bebê, e o anúncio da soropositividade ao seu parceiro. A Sra. J. afirma que o Cavalheiro nunca mais voltou a falar disso. Eu lhe pergunto se ela, por seu lado, tentou evocar o assunto, ela responde que não, parecendo espantada de que eu lhe fizesse tal pergunta. De fato pensa que cabe a ele falar disso com ela.

Enumero para ela os acontecimentos que ela mencionou: "a senhora teve um primeiro filho com o Cavalheiro, vocês se separaram durante um período, a senhora engravidou novamente e disseram ao Cavalheiro que a senhora acabava de descobrir, por ocasião dessa gravidez, que era HIV-positiva. O que ele pode pensar?” A Sra. J. não sabe o que dizer, e volta a falar de seus temores quanto à vida cotidiana que virá e, no final da entrevista, evoca seu medo de 
não poder arranjar outro homem, uma vez que está soropositiva: “sim, quem vai me querer?"

Como falar de confiança com alguém que não disse a verdade? Uma mulher me dizia que, cheia de remorsos, terminara por dizer ao marido que já sabia que era soropositiva por ocasião da gravidez do primeiro filho, e não na do último. O Cavalheiro então lhe respondeu: "E por que eu deveria acreditar nisso que você está dizendo, e que você não continua mentindo?" O tema da confiança é recorrente nas pessoas contaminadas pelo HIV. Fazer o outro correr riscos quando a gente se coloca dentro da confiança no outro, e do outro, em seu envolvimento numa vida de casal, corresponde a uma parte inconsciente de um desejo de anular a diferença.

Ao que me parece, em todas essas situações não nos detivemos a apreender o efeito deletério da não-comunicação dentro do casal. O anúncio não tem o alcance com que se conta se a troca emocional não é favorecida. Minha experiência me fez ver que a violência do dizer ou do não-dizer depende da qualidade da troca afetiva por ocasião do anúncio. De fato, o anúncio do diagnóstico, e uma informação sobre a doença feita a um terceiro, mesmo na presença da pessoa a que se refere, ficam cindidos no espírito do terceiro se a informação não for retomada entre esse terceiro e a pessoa a que se refere. Essa informação precisa ficar inscrita numa troca em que os afetos tomam seu lugar dentro do casal, mesmo que sejam da ordem da incompreensão, da rejeição e da cólera num primeiro tempo.

Esse peso do silêncio, das mentiras, dos não-ditos e em algum lugar de dizer a verdade (que é um peso, se não for assumida, isto é, integrada em sua história de vida), se declina em múltiplas situações, ligadas à gravidez e à chegada do bebê. De fato, as questões dessas mulheres são de saber como responder a quem está à volta, a propósito: do início do tratamento ao final da gravidez, da eventual cesariana, os tratamentos, os exames e as consultas do bebê no hospital, o fato de ter que amamentar artificialmente o filho, as inquietações, o cansaço e as angústias até o anúncio do diagnóstico da criança, quando ela tiver mais ou menos 3 meses, e sempre as ansiedades por sua própria saúde, etc. Nessas reflexões, costumo ser levada a acompanhá-las quanto a distinguir aquilo que é da esfera do íntimo, do privado e do público. Realmente, o que é que é preciso compartilhar de si mesma, e com quem? Que sentido isso adquire em tal momento de sua vida, e na situação dada. É bastante frequente que nos aconteça de conhecer mulheres sozinhas. São grávidas HIV-positivas, mas nunca houve um projeto de casal.

O tempo da gravidez é um período perturbador, um tempo de remanejamento psíquico que põe novamente em dinâmica as problemáticas de vida, de morte, e de continuidade de gerações, com um passivo de conflito e de alegria por sua 
própria história familiar. Na situação de uma sorologia para HIV, essas problemáticas de vida e de morte se tornam muito mais conscientes. Nos múltiplos casos de mulheres sozinhas, não se trata de um projeto de casal de transmitir a vida, mas de um projeto pessoal de mulher, mais ou menos consciente, estreitamente ligado ao "pró e contra" o vírus, num relacionamento de onipotência quanto à morte.

Dentro do enquadre do acompanhamento de mulheres grávidas soropositivas, recebemos muitas pessoas originárias da África, por isso vou me deter a fazer algumas observações sobre isso. A precariedade e a migração são dois fatores que aumentam as dificuldades de esperar uma criança, sendo soropositiva.

A precariedade faz com que as condições do ambiente não ofereçam garantias de proteção para esperar, acolher e ter um bebê (não há alojamento fixo, não há recursos, há demandas de auxílio de instituições de caridade e instituições sociais, há ausência de referenciais familiares e sociais, etc.). A migração, por seu lado, implicou ruptura com os ambientes cultural e familiar conhecidos e capazes de oferecer alguma segurança e que, naturalmente, na grande maioria dos casos, estão presentes para apoiar os períodos em torno do parto e o início da maternagem.

Na França a maioria dessas famílias se encontra em situação irregular e é, paradoxalmente, "graças" à sua condição de soropositivas que essas pessoas vão obter sua permissão de moradia, com as dificuldades para um cônjuge não soropositivo, no caso de casais em que há essa diferença de sorologias. A complexidade se estende à comunidade em que a pessoa se encontra na França, e da qual é mais frequente que a pessoa esconda seu estatuto sorológico, o que engendra todas as dificuldades: como explicar a obtenção de seus documentos, o acesso a um alojamento, a cesariana, o aleitamento artificial, etc. Várias pessoas têm igualmente a preocupação de ter deixado filhos no país de origem, e para algumas há ainda a preocupação quanto ao seu diagnóstico.

Constatamos, então, toda a dificuldade que essas mães têm para poder adaptar-se "suficientemente" a seu filho, se seu espírito está constantemente ocupado com o temor pelo amanhã e pela urgência, tanto do ponto de vista social quanto pelo fato do HIV.

Vou concluir com esta observação: mesmo no contexto da soropositividade ao HIV, a gravidez é um importante momento de abertura e remanejamento que é preciso aproveitar para apoiar a dinâmica da vida psíquica que impulsiona a vida, e em sua ligação aos outros, a fim de proteger as relações de casal e de pais e filhos.

Aprovado em 5/3/2008. 


\section{BIBLIOGRAFIA}

BERREBI, A. (2001) Le SIDA au féminin. Paris: Doin.

CHARTIER, D., MATOT, J-P. (1991) “Vivre ou mourir d'enfant — quelques réflexions sur le désir d'enfant, la grossesse et la maternité chez des femmes séropositives pour le VIH". Neuropsychiatrie de l'Enfance et de l'adolescence, n.39 (1), p.39-46.

CHAUVARD, S., COUMAU, C. (1997) “Sida au féminin”. Impact médecin hebdo, n.387, 28 nov, p.6-15.

LEGUIL, F., SILVESTRE, D. (1988) "Psychanalystes confrontés au SIDA". Ornicar, n.45, avril-juin, p.5-13.

MANDELBROT, L. (1999) "La prise en charge des femmes enceintes séropositives”, entretien, propos recueillis par Maraschin, J. Le journal du sida, n.120-121, décembre, p.6-8.

MARTIN-CHABOT, B. (2001) "Les épreuves du sida et les images en famille”. Le divan familial, 7/Automne, p.87-100.

MORO, M.-R., IDRISS, I. (1996) "Vivre malgré le sida. Survivre à la mort culturelle". in Sida et vie psychique - Approche clinique et prise en charge, dir. Hefez, S. Paris: La Découverte, p.268-274.

THOME-RENAUD, A. (1995) Le traumatisme de la mort annoncée. Psychosomatique et sida. Paris: Dunod.

ACTES DU COLLOQUE DE L'ASSOCIATION “DESSINE MOI UN MOUTON”. (2002) "Le suivi pré et postnatal de la femme séropositive. Quel suivi pluridisciplinaire?”, le 11 déc. 2001 à Paris, Maury SA.

WINNICOTT, D. W. (1952/1992) “L’angoisse associée à l'insécurité”. in De la pédiatrie à la psychanalyse. Paris: Payot.

Béatrice Martin-Chabot

livrariamuseu@uol.com.br 